УДК 336.14:352

DOI: https://doi.org/10.37320/2415-3583/9.9

Безпалько О.М.

аспірантка,

Донецький наџіональний університет імені Василя Стуса

\title{
ФІНАНСОВА СПРОМОЖНІСТЬ ОБ'ЄДНАНИХ ТЕРИТОРІАЛЬНИХ ГРОМАД: ПРОБЛЕМИ ТА ПЕРСПЕКТИВИ ЗАБЕЗПЕЧЕННЯ
}

У статті проаналізовано актуальні проблеми та напрями забезпечення фінансової й економічної спроможності об'єднаних територіальних громад у контексті потреби модернізації моделі управління їх розвитком. Обтрунтовано, що ефективність фінансового менеджменту як складової моделі управління громадою є значушим чинником, який забезпечує ресурсний потенціал розвитку через зростання фінансової спроможності громади. Продемонстровано, щзо діяльність, спрямована на забезпечення фінансової спроможності громади, водночас стимулює розвиток інших місиевих ресурсів, тобто є фундаментом для досягнення иілей децентралізації. Визначено, щзо можливості громади реалізувати успішну модель управління фінансовою спроможністю обмежені комплексом інституиійних чинників, серед яких важливою є нестабільність регулювання, зумовлена постійними змінами Бюджетного кодексу Украӥни та порядків нарахування різного роду субвенцій $і$ дотацій. Запропоновано комплекс рекомендацій щзодо доопраџювання, внесення змін до законодавчої бази на основі врахування досвіду його практичного застосування для розвитку громад.

Ключові слова: об'єднані територіальні громади, управління розвитком громад, фінансова спроможність.

Постановка проблеми. Формування та зміцнення територіальних громад в Україні є процесом, спрямованим на вирішення актуальних завдань людського розвитку: підвищення рівня та якості життя всіх категорій населення, подолання несправедливої територіальної диференціації зазначених показників, яка зумовлена обмеженим доступом значної частини громадян України до суспільних благ. Процес децентралізації в Україні вже демонструє позитивний результат вирішення окреслених питань, що $є$ можливим на основі досягнення принципових цілей, заради яких об'єднуються територіальні громади: отримання економічної та податкової самостійності, набуття самостійних функцій, які фактично надають об'єднаним територіальним громадам статус, наближений до нинішнього статусу міст обласного значення. Інституційна умова втілення ідеї децентралізації передбачала фіксацію у Бюджетному кодексі ще на початку 2015 р. джерел надходжень бюджетів об'єднаних територіальних громад (далі - ОТГ), визначення функцій ОТГ через закріплення видатків, які здійснюються 3 бюджету ОТГ.

На етапі реалізації цієї політики очевидними стали проблеми, які продемонстрували обмежені можливості громади забезпечити фінансову спроможність на основі місцевих податків, порядку нарахування субвенцій i дотацій, формування бюджету, залучення інвестицій тощо. Причина пов'язана $з$ нестабільністю передбаченого регулювання, формою прояву якої є постійні зміни Бюджетного кодексу та порядків нарахування різного роду субвенцій і дотацій, що не давало можливість громадам ефективно планувати свою діяльність [2].
Ще від початку впровадження реформи децентралізації влади було визначено, що одними 3 головних чинників, які стимулюватимуть утворення об'єднаних територіальних громад, стануть фінансові стимули та бюджетна автономія ОТГ $[8 ; 11]$. Спроможні ОТГ переходили на прямі міжбюджетні відносини 3 державним бюджетом, а також напряму отримували передбачені Бюджетним кодексом субвенції і дотації для виконання окремих функцій, а крім того - субвенції на формування відповідної інфраструктури та соціально-економічний розвиток.

Водночас протягом реалізації реформ у Бюджетному кодексі відбувалися численні зміни, і багато ОТГ відзначають, що держава делегує громадам усе більше і більше власних повноважень, для виконання яких створюються відповідні структури, збільшується фонд заробітної плати та виділяються кошти 3 місцевого бюджету, але фінансування на виконання цих повноважень не виділяється. Заможні громади можуть утримувати всі ці структури, а бідним із кожним роком це ставатиме складніше. Новим аспектом цього процесу $є$ передача державою повноважень у сфері соціального захисту, видатки на виконання яких $\epsilon$ досить суттєвими.

Аналіз останніх досліджень i публікацій. Питанням фінансового забезпечення розвитку об'єднаних територіальних громад приділяє увагу велика кількість учених, особливо в наукових працях останніх трьох років, серед них: B.I. Варцаба [3], Л.В. Слухарська [15], Т.С. Ганзицька [4], Н.В. Корець [9], Я.В. Казюк [6]. Із боку практичного застосування висвітлюють питання бюджетної децентралізації О.Г. Чубарь [16], К.С. Машіко [16]. Децентралізацію повноважень місцевих гро- 
мад розглядають А.П. Лелеченко, О.І. Васильєва, В.С. Куйбіда, А.Ф. Ткачук [10].

Мета статті полягає в ідентифікації актуальних проблем та напрямів забезпечення фінансової й економічної спроможності об'єднаних територіальних громад та обгрунтуванні на цій основі напрямів формування ефективної моделі управління розвитком громад.

Виклад основного матеріалу. Відповідно до Європейської хартії місцевого самоврядування, яка була схвалена Радою Свропи 15 жовтня 1985 р., спроможність є ключовою характеристикою місцевого самоврядування, а також муніципальних утворень, які в Україні набувають форми територіальних громад.

Спроможні територіальні громади - це «територіальні громади сіл (селищ, міст), які в результаті добровільного об'єднання здатні самостійно або через відповідні органи місцевого самоврядування забезпечити належний рівень надання послуг, зокрема у сфері освіти, культури, охорони здоров'я, соціального захисту, житлово-комунального господарства, з урахуванням кадрових ресурсів, фінансового забезпечення та розвитку інфраструктури відповідної адміністративнотериторіальної одиниці» [7].

Однією $з$ головних проблем, що виникають під час організації ОТГ, є проблема забезпечення їх реальної спроможності. У цьому разі ключовим чинником $\epsilon$ наявність відповідних кадрових ресурсів, фінансового забезпечення та розвитку інфраструктури.

В існуючих дослідженнях фінансова спроможність соціально-економічного розвитку просторової системи визначається як єдність достатності фінансового потенціалу утворення, результативності використання фінансових ресурсів та можливості самостійного забезпечення соціальноекономічного розвитку [12]. Отже, фінансову спроможність муніципального утворення (або ОТГ) доцільно визначити як його здатність забезпечувати надходження у достатньому обсязі фінансових ресурсів, формувати ефективну структуру їх джерел, здійснювати якісний розподіл фінансових ресурсів, сприяти їх ефективному використанню для подолання дестабілізаторів, а також створювати умови для досягнення стабільності соціально-економічного розвитку ОТГ у короткостроковій та довгостроковій перспективі.

Проведене дослідження сучасних наукових напрацювань дає змогу зробити висновок, що в процесі створення ОТГ можна виділити три види фінансової спроможності:

потенціальну, чи розрахункову, спроможність, якою мають володіти громади, визначені такими відповідно до перспективного плану;

спроможність, яка юридично визнається Кабінетом Міністрів України відповідно до ст.
9 Закону України «Про добровільне об'єднання територіальних громад»;

реальну спроможність, яка визначається вже після того, як ОТГ сформована і показує певні результати діяльності [1].

Фінансова спроможність громад є запорукою добробуту кожної території зокрема та інструментом регіонального розвитку, тобто в процесі реалізації реформ та делегування державою повноважень громадам виникають нові можливості, що системно мають впливати на спроможність та самостійність об'єднаних територіальних громад. Водночас маємо констатувати нелогічність та незавершеність певних кроків у цьому напрямі: розширення повноважень переважно не супроводжується очікуваним збільшенням фінансування на реалізацію цих повноважень, що, своєю чергою, паралізує основну діяльність органів місцевого самоврядування, які до цих викликів не готові. Типовим прикладом є рішення щодо передачі громадам повноважень у сфері соціального захисту, для реалізації чого громади мають самостійно створити для працівників робочі місця, забезпечити оргтехнікою, хоча кошти для цього передбачені відповідними фондами державного рівня.

Ще одним прикладом подібної неузгодженості $\epsilon$ проблема 3 пільговими перевезеннями: держава мала б передбачити механізм компенсації такого виду перевезень шляхом надання окремої субвенції, а фактично ОТГ іï не отримують. Проблемою $є$ те, що субвенція спрямовується на рахунки винятково головних розпорядників коштів, а ОТГ такими не $\epsilon$, тому кошти заходять на райони, які, своєю чергою, розподіляють субвенцію. У результаті до ОТГ надходить із району значно менше коштів, аніж фактичний розмір компенсації пільгових перевезень (за оцінками громад, обсяг фактичних надходжень становить лише 30\% від потреби). За таких умов ОТГ вимушені дофінансовувати пільгові перевезення за рахунок власних коштів, можливості для чого є обмеженими [5].

Важливим аспектом зазначеної проблеми $\epsilon$ також недотримання державою термінів фінансування. Типовою є ситуація, коли субвенція надходить зі значним запізненням, що суттєво обмежує можливості громади вчасно використати кошти через тривалий термін проведення тендерних процедур. Результатом часто є повернення грошей державі як невикористаних протягом фінансового періоду. У цьому контексті актуальним є завдання обгрунтування рекомендацій щодо внесення змін у тендерне законодавство України та регламент процесу закупівель за бюджетні кошти.

Отже, є підстави констатувати, що на виконання делегованих громадам повноважень держава не виділяє достатнього обсягу фінансування та спричинює додаткові проблеми через неста- 
більність надходжень. Сьогодні спостерігається швидке збільшення кількості ОТГ без пропорційного збільшення обсягу субвенції на розвиток інфраструктури, що знижує мотивацію громад до об'єднання та обмежує можливості концентрації ресурсів на соціально-економічний розвиток. У 2016 р. державна субвенція на інфраструктуру громад становила 1 млрд грн і була розподілена між бюджетами 159 ОТГ пропорційно до площі громади та кількості сільського населення. У 2019 р. обсяг субвенції передбачено в розмірі 1,5 млрд грн, тоді як кількість громад, між якими ці кошти мають бути розподілені, становить 806. Очевидним $є$ створення нерівних умов та нерівних стимулів для ОТГ, які об'єдналися в останні роки, порівняно з тими, хто об'єднався одразу в 2015 p. [13].

Одним із головних фінансових стимулів для ОТГ було отримання $60 \%$ податку на доходи фізичних осіб (далі - ПДФО). Відповідно до ст. 64 Бюджетного кодексу [2], було визначено, що ПДФО сплачується податковим агентом - фізичною особою за місцем реєстрації, а юридичною особою (або iï філією, відділенням, іншим відокремленим підрозділом) - за їх місцезнаходженням (розташуванням). Це мало вирішити питання надходжень до бюджетів ОТГ податків від підрозділів юридичних осіб, що розташовані в ОТГ, притому що сама юридична особа зареєстрована в іншому місці (часто в обласному центрі або навіть у столиці). Фактично ж виникла суперечність між Бюджетним і Податковим кодексами, оскільки для податкових органів не визначено поняття «місцезнаходження», а існує тільки реєстрація. За таких умов фіскальні органи нараховували сплату ПДФО за місцем реєстрації юридичної особи, через що багато ОТГ зазнали суттєвих утрат щодо очікуваних обсягів податкових надходжень. Це досить негативна ситуація, адже такі установи використовують інфраструктуру громади, а натомість не сплачують у бюджет громади податків. Окрім того, багато юридичних осіб не реєструють свої філії як окремі юридичні особи, що теж не дає змоги зарахувати ПДФО 3 працюючих у цих філіях працівників до бюджету відповідної ОТГ. Зазначену невідповідність між задекларованим та фактичним станом має виправити узгодження положень Бюджетного і Податкового кодексів із метою зарахування ПДФО до бюджетів тих громад, де фактично працюють філії або відокремлені підрозділи юридичних осіб (у т. ч. без окремого юридичного статусу). Також корисним для України $є$ впровадження досвіду Польщі, який передбачає можливість визначення самим платником ПДФО бюджету, до якого він може зараховуватися у разі, якщо фактичне місце проживання відрізняється від офіційного.
Пов'язаним щодо сплати ПДФО питанням $€$ нарахування акцизів. У 2015 р. Бюджетним кодексом [2] передбачалося, що акцизний податок на паливо, тютюнові та алкогольні вироби, що реалізуються на території ОТГ, зараховується до бюджету цієї ОТГ. Громади отримали до своїх бюджетів значні кошти, зокрема надходження 3 однієї заправки становили 1-2 млн грн за рік. У 2016 р. було введено адміністрування урядом акцизу на паливо для ОТГ, який призвів до ситуації, коли цей акциз збирається до державного бюджету, де використовується декілька місяців перед надходженням до ОТГ. Причому практика показала, що такий механізм виявився негативним для громад, які у фактичному розрахунку почали отримувати менше коштів у вигляді акцизу порівняно із ситуацією, за якої акциз надходив напряму до бюджету ОТГ. Окрім того, у керівництва ОТГ фактично зник стимул контролювати обсяги реалізації підакцизних товарів (насамперед палива), оскільки відсутня пряма залежність між обсягами реалізації палива на конкретній заправній станції та надходженнями в бюджет ОТГ. Проблемою є також те, що нарахування акцизу на паливо відбувається за місцем реєстрації касового апарату, а він не завжди відповідає фактичному місцезнаходженню заправки. Ця проблема потребує комплексного вирішення на нормативно-правовому рівні, і громади вважають механізм прямого надходження акцизу від палива до бюджету ОТГ більш доцільним та економічно вигідним.

Ще однією проблемою, яку часто відзначають громади, $є$ необхідність роботи через Казначейство, яке має складні, тривалі і бюрократичні процедури [5]. Водночас якщо ОТГ відкриє рахунок в іншому банку, Казначейство не покриває обсяги тимчасових касових розривів таких громад, що може призвести до виникнення дефіциту коштів, наприклад у період, коли відбувається масова відпускна кампанія. Тому наявність у ОТГ рахунків в інших банківських установах, окрім Казначейства, це скоріше винятки.

Також чинником, що негативно впливає на формування бази податкових надходжень ОТГ, є питання земельних ресурсів. До початку реформи в управлінні органів місцевого самоврядування перебувала виключно земля в межах населених пунктів. Землі за межами населених пунктів перебували в управлінні Держгеоземкадастру, що фактично призводило до неможливості використання цих земель для залучення потенційних інвесторів та відсутності механізмів впливу керівництва громад на діючих користувачів земель. У 2018 р. розпочався процес передачі земель сільськогосподарського призначення за межами населених пунктів в управління ОТГ [6]. Це був необхідний крок, адже в 2018 р. плата за землю становила понад $13 \%$ від загальних доходів бюджетів ОТГ. Повна 
передача земель сільськогосподарського призначення у власність громади теоретично може значно збільшити цей відсоток. Водночас виникла низка проблем у реалізації цього процесу. Так, відсутня інвентаризація земель. Кабінет Міністрів задекларував (і є відповідний наказ Держгеоземкадастру), що інвентаризація земель буде проводитися за кошти державного бюджету і передача земель в управління ОТГ відбудеться після завершення такої інвентаризації. У реальності цей процес занадто затягується, що призводить до неможливості передачі земель в управління ОТГ. Більше того, громади зазначають, що дані, наявні в базах Держгеоземкадастру, є неточними і неповними. Документи на землю зберігаються здебільшого в паперовому вигляді, а якісного електронного реєстру взагалі не існує. Більше того, основний масив зберігається в районних управліннях земельних ресурсів. Яскравим є приклад Чкалівської ОТГ у Харківській області. Держгеокадастр пропонував передати у власність громади 1 155,7 га земель. Проведення інвентаризації з боку громади показало значно більші цифри. Як наслідок, у комунальну власність громади було передано 3800 га, тобто понад у три рази більше, ніж пропонувалося на початку.

Окремо варто відзначити ще один аспект проблематики земельних ресурсів в ОТГ - більшість земель уже передано в користування. Передача земель у власність громади мала на меті створити можливість розпоряджатися землею на свій власний розсуд та отримувати від цього податкові надходження. Але це все не стосуватиметься земель, що вже були передані у користування. Як наслідок, громада лише в теорії отримує великий ресурс, але жодним чином не може вплинути на нього. Більше того, в разі передачі у власність громади вже орендованої ділянки має бути отримана згода від орендаря. Якщо цього не буде зроблено, громада нічого не отримає. I це є не єдиним негативним наслідком. Після закінчення терміну оренди ділянки виставляються на аукціон, де перемагає той, хто зможе запропонувати найвищий відсоток орендної плати. I найчастіше таким переможцем буде не місцевий фермер, а великий агрохолдинг, зареєстрований не на території громади. Як наслідок, податки сплачуватимуться за місцем реєстраціï, а не до місцевого бюджету.

Однією 3 найбільш складних для вирішення проблем більшості громад на етапі забезпечення фінансової спроможності є низький рівень залучення потенційних інвесторів. Фактично лише після свого утворення ОТГ отримали можливість залучення інвесторів за рахунок використання земельних ресурсів за межами населених пунктів, створення стимулів та пільг для інвесторів (через самостійне управління розмірами місцевих податків) i рекламу власного інвестиційного потен- ціалу. Часто громади не мають досвіду в такій діяльності і, відповідно, не мають жодних планів розвитку інвестиційної привабливості територій. Напрацювання таких планів часто є неможливим через відсутність працівників із відповідним рівнем підготовки, а залучення зовнішніх експертів $\epsilon$ дорогим. Тому здебільшого напрацювання у сфері залучення інвесторів та розвитку інвестиційної привабливості громад $є$ наслідком участі в різних програмах.

Комплекс проблем, якими супроводжується процес забезпечення фінансової спроможності громад в Україні, зумовлює потребу обгрунтування та реалізації низки напрямів, пов'язаних i3 поєднанням інструментів інституційного та нормативно-правового регулювання на рівні держави, та самостійних кроків громад у напрямі посилення власної спроможності приймати коректні рішення щодо раціонального використання наявних ресурсів, захисту інтересів громади. Тобто сприятлива політика держави буде набувати максимальної продуктивності лише за умови зростання управлінської компетентності фахівців, які приймають рішення на місцевому рівні та діють у межах сучасної управлінської моделі, яка забезпечує ефективність кожного процесу, результат якого працює на зміцнення громади та кожного їі жителя.

Виходячи з вищезазначеного, для забезпечення фінансової та економічної спроможності ОТГ доцільно запропонувати такі заходи:

сформувати чітку структуру розподілу повноважень та фінансових ресурсів за рівнями бюджетів (державний, обласні, об'єднаних територіальних громад або міст обласного значення);

законодавчо врегулювати надання дозволу громадам управляти власними земельними ресурсами, що сприятиме зміцненню матеріальної та фінансової основи місцевого самоврядування, якісному плануванню розвитку території;

дати змогу зараховувати до бюджетів ОТГ частину коштів від податку на прибуток підприємств, які діють на їхній території;

звільнити суб'єкти підприємницької діяльності від сплати частини податку на прибуток підприємств під час фінансування ними проєктів, які сприятимуть розвитку місцевого самоврядування та поліпшенню благоустрою територій громад, у яких вони проводять свою діяльність.

Висновки. На державному рівні затребуваним iз боку суспільства $є$ термінове оприлюднення урядом остаточного формату очікуваної адміністративно-територіальної реформи, яка має підтримати політику децентралізації, ліквідувати розбіжність між задекларованими пріоритетами й намірами та станом їх фактичної реалізації. Парламент, своєю чергою, має внести зміни до чинних законів або розробити нові законопроєкти, 
необхідні для завершення реформи. Критичною умовою успішності зазначених заходів має бути посилення та реальне забезпечення стимулюючого впливу державного нормативно-правового регулювання на зміцнення потенціалу громад. Рекомендації щодо вдосконалення Бюджетного кодексу України мають бути спрямовані на забезпечення достатньої фінансової бази для повноцінної діяльності органів місцевого самоврядування громад та надання місцевим радам можливості використання інструментів місцевого розвитку на своїй території (ліквідація централізованого розподілу окремих видів податків та акцизів, розширення переліку місцевих податків, зарахування окремих видів адміністративних зборів до місцевих бюджетів тощо). Окремим напрямом забезпечення реальної фінансової спроможності громадами $є$ набуття актуальних знань та досвіду у сфері управління власними ресурсами фахівцями, відповідальними за вибір напряму розвитку та прийняття управлінських рішень на місцевому рівні.

\section{Список використаних джерел:}

1. Бібік Н.В., Шаповал Г.М. Аналіз міжнародного досвіду розвитку територіальних громад та визначення напрямків його впровадження в Україні. Сучасний стан наукових досліджень та технологій у промисловості. 2019. № 2(8). С. 5 -14.

2. Бюджетний кодекс України. URL : http://zakon1.rada.gov.ua/laws/show/2456-17 (дата звернення: 15.02.2020).

3. Варцаба В.І., Мулеса Е.В. Реалізація фінансової децентралізації: виклики та досягнення громад. Причорноморські економічні студіï. 2018. Вип. 28-2. URL : http://bses.in.ua/journals/2018/28 2 2018/21.pdf (дата звернення: 20.02.2020).

4. Ганзицька Т.С., Козін В.В. Місцеві бюджети в контексті фінансової децентралізації. Науковий вісник Херсонського національного університету. Юридичні науки. 2017. Вип. 1. С. 22-26.

5. Громадська думка населення щодо реформи децентралізації / Фонд «Демократичні ініціативи» імені Ілька Кучеріва.

URL : https://dif.org.ua/article/detsentralizatsiya-dosyagnennya-i-problemi-otsinki-gromadyan (дата звернення: 17.02.2020).

6. Казюк Я.В. Громади наростили надходження від плати за землю - ці та інші дані бюджетів громад за 10 місяців. URL : http://decentralization.gov.ua/ news/7516 (дата звернення: 16.02.2020).

7. Козіна В. Формування спроможних територіальних громад. Держслужбовеиьь. 2015. № 5. URL : https://i.factor.ua/ ukr/journals/ds/2015/may/issue-5/article-7879.html (дата звернення: 18.02.2020).

8. Концепція реформування місцевого самоврядування та територіальної організації влади в Україні. URL : http://zakon4.rada.gov.ua/laws/show/333-2014-\%D1\%80 (дата звернення: 15.02.2020).

9. Корець Н.В. Бюджетна децентралізація в Україні: результати реформи та пріоритети розвитку. Економіка. Стратегії розвитку. 2017 № 2(43). С. 81-88.

10. Місцеве самоврядування в умовах децентралізації повноважень / А.П. Лелеченко та ін. Київ, 2017. 110 с.

11. Методика формування спроможних територіальних громад : Постанова Кабінету Міністрів № 214 від 08.04.2015. URL : https://zakon.rada.gov.ua/laws/show/214-2015-\%D0\%BF (дата звернення: 19.02.2020).

12. Михайлів Г. Фінансова спроможність соціально-економічного розвитку регіональних суспільних систем. Економічний аналіз. 2010. № 7. С. 97-99.

13. Офіційний сайт Асоціації міст України. URL : https://www.auc.org.ua/ (дата звернення: 10.02.2020).

14. Про добровільне об’єднання територіальних громад : Закон України від 05 лютого 2015 р. № 157-19 / Верховна Рада України. URL : http://zakon4.rada.gov.ua/laws/show/157-19 (дата звернення: 09.02.2020).

15. Сухарська Л.В. Аналіз стану фінансового забезпечення розвитку об'єднаних територіальних громад у сучасній Україні. URL : http://www.e-patp.academy.gov.ua/pages/dop/19/les/fb4bab59-69c4-415d-b4b0-cac93834d1ba.pdf (дата 3вернення: 12.02.2020).

16. Чубарь О.Г., Машіко К.С. Децентралізація і фінансове забезпечення територіальної громади. Науковий вісник Ужгородського національного університету. Серія «Економіка». 2016. № 1(47). С. 419-426.

\section{References:}

1. Bibik N. V., Shapoval H. M. (2019) Analiz mizhnarodnoho dosvidu rozvytku terytorialnykh hromad ta vyznachennia napriamkiv yoho vprovadzhennia v Ukraini [Analysis of international experience of development of territorial communities and determination of directions of its implementation in Ukraine]. Suchasnyi stan naukovykh doslidzhen ta tekhnolohii $v$ promyslovosti [The current state of research and technology in industry], No 2 (8), pp. 5-14 (in Ukrainian).

2. Biudzhetnyi Kodeks Ukrainy [Budget Code of Ukraine]. URL: http://zakon1.rada.gov.ua/laws/show/2456-17 (accessed 15 February 2020) (in Ukrainian).

3. Vartsaba V.I., Mulesa E.V. (2018) Realizatsiia finansovoi detsentralizatsii: vyklyky ta dosiahnennia hromad [Implementing Financial Decentralization: Challenges and Community Achievements]. Prychornomorski ekonomichni studii [Black Sea Economic Studies], Vol. 28-2. URL: http://bses.in.ua/journals/2018/28 2 2018/21.pdf (accessed 20 February 2020) (in Ukrainian).

4. Hanzytska T.S., Kozin V.V. (2017) Mistsevi biudzhety v konteksti finansovoi detsentralizatsii [Local budgets in the context of financial decentralization]. Naukovyy visnyk Khersonskoho natsionalnoho universytetu. Yurydychni nauky [Scientific Bulletin of the Kherson National University. Law.], Vol. 1, pp. 22-26 (in Ukrainian).

5. Hromadska dumka naselennia shchodo reformy detsentralizatsii [Public Opinion on Decentralization Reform] / Fond «Demokratychni initsiatyvy» imeni Ilka Kucheriva [Ilko Kucheriv Democratic Initiatives Foundation]. URL: https://dif.org.ua/ article/detsentralizatsiya-dosyagnennya-i-problemi-otsinki-gromadyan (accessed 17 February 2020) (in Ukrainian).

6. Kaziuk Ya.V. Hromady narostyly nadkhodzhennia vid platy za zemliu - tsi ta inshi dani biudzhetiv hromad za 10 misiatsiv [Communities have increased their land payments - these and other community budgets over a 10-month period]. URL: http://decentralization.gov.ua/ news/7516 (accessed 16 February 2020) (in Ukrainian). 
7. Kozina V. (2015) Formuvannia spromozhnykh terytorialnykh hromad [Formation of capable territorial communities]. Derzhsluzhbovets [ivil servant], No 5. URL: https://i.factor.ua/ukr/journals/ds/2015/may/issue-5/article-7879.html (accessed 18 February 2020) (in Ukrainian).

8. Kontseptsiia reformuvannia mistsevoho samovriaduvannia ta terytorialnoi orhanizatsii vlady v Ukraini [The concept of reforming local self-government and territorial organization of government in Ukraine]. URL: http://zakon4.rada.gov.ua/laws/ show/333-2014-\%D1\%80 (accessed 15 February 2020) (in Ukrainian).

9. Korets N.V. (2017) Biudzhetna detsentralizatsiia v Ukraini: rezultaty reformy ta priorytety rozvytku [Budget decentralization in Ukraine: reform outcomes and development priorities]. Ekonomika. Stratehii rozvytku [Economy. Development strategies], No 2 (43), pp. 81-88 (in Ukrainian).

10. Lelechenko A. P., Vasylieva O. I., Kuybida V. S., Tkachuk A. F. (2017) Mistseve samovriaduvannia v umovakh detsentralizatsii povnovazhen [Local self-government in the conditions of decentralization of powers]. Kyiv. 110 p. (in Ukrainian).

11. Metodyka formuvannia spromozhnykh terytorialnykh hromad: Postanova Kabinetu Ministriv No 214 vid 08.04.2015 r. [Methods of formation of capable territorial communities: Resolution of the Cabinet of Ministers No 214 of 08.04.2015] URL: https://zakon.rada.gov.ua/laws/show/214-2015-\%D0\%BF (accessed 19 February 2020) (in Ukrainian).

12. Mykhailiv H. (2010) Finansova spromozhnist sotsialno-ekonomichnoho rozvytku rehionalnykh suspilnykh system [Financial capacity of socio-economic development of regional social systems]. Ekonomichnyi analiz [Economic analysis], No 7, pp. 97-99 (in Ukrainian).

13. Ofitsiinyi sait Asotsiatsii mist Ukrainy [Official site of the Association of Ukrainian Cities]. URL:: https://www.auc.org.ua/ (accessed 10 February 2020) (in Ukrainian).

14. Pro dobrovilne obiednannia terytorialnykh hromad: Zakon Ukrainy vid 05 liutoho 2015 r. No 157-19 [On voluntary association of territorial communities: Law of Ukraine of February 05, 2015 No 157-19] / Verkhovna Rada Ukrainy [The Verkhovna Rada of Ukraine]. URL: http://zakon4.rada.gov.ua/laws/show/157-19 (accessed 09 February 2020) (in Ukrainian).

15. Sukharska L.V. Analiz stanu finansovoho zabezpechennia rozvytku obiednanykh terytorialnykh hromad u suchasnii Ukraini [Analysis of the state of financial support for the development of united territorial communities in modern Ukraine]. URL: http://www.e-patp.academy.gov.ua/pages/dop/19/les/fb4bab59-69c4-415d-b4b0-cac93834d1ba.pdf (accessed 12 February 2020) (in Ukrainian).

16. Chubar O.H., Mashiko K.S. (2016) Detsentralizatsiia i finansove zabezpechennia terytorialnoi hromady [Decentralization and financial support of the territorial community]. Naukovyi visnyk Uzhhorodskoho natsionalnoho universytetu. Seriia «Ekonomika» [Scientific Bulletin of Uzhgorod National University. Economy series], No 1 (47), pp. 419-426 (in Ukrainian).

Bezpalko Olga

Vasyl' Stus Donetsk National University

\section{FINANCIAL CAPACITY OF AMALGAMATED LOCAL COMMUNITIES: PROBLEMS AND PERSPECTIVES}

The purpose of the article is to identify the current problems and directions of ensuring the financial and economic capacity of the amalgamated local communities and substantiation on this basis of directions of forming an effective model of communites development management. Communities financial capacity is a source of prosperity for each territory and a tool for regional development. New opportunities arise in the process of implementing reforms and delegating state power to communities, which should systematically affect the capacity and autonomy of communities. At the same time, we establish the lack of logic and incompleteness of certain steps in this direction: enlargement of communities authority is generally not accompanied by an expected financing increase to carry out that authority, which results in paralysing the main activity of communities that are not ready for these challenges. Methods of analysis, synthesis, comparison, systematic analysis, abstraction and logical generalization were used in the following research in order to identify and systematize the problems and directions of ensuring of financial and economic capacities of amalgamated local communities. The research substantiates that the effectiveness of financial management as an integral community management model is a significant factor that provides resource development potential through increasing financial capacity of the community. It has been demonstrated that the activity is aimed to ensure the financial capacity of the community at the same time stimulates the development of other local resources, thus, it is the foundation for achieving the goals of decentralization. The ability of the community to implement a successful model of financial capacity management is determined to be a limited complex of institutional factors, among which the important one is instability of regulation due to the constant changes of the Budget Code of Ukraine and the procedures for assessing various subsidies and grants. The practical value of the article is to develop a set of recommendations for finalization, amendment to legislative framework based on the experience of its practical application for communities development.

Key words: amalgamated local communities, community development management, financial capacity of communities, financial management.

JEL classification: $\mathrm{H} 72, \mathrm{H} 77$. 